\title{
THE EFFECT OF FESTIVAL QUALITY ON REVISIT INTENTION: MEDIATING ROLE OF DESTINATION IMAGE IN JEMBER FASHION CARNAVAL, JEMBER, INDONESIA
}

\author{
SUPRIONO* \\ Brawijaya University, Faculty of Administration Science, MT. Haryono 163, Malang, Indonesia, e-mail: supriono_fia@ub.ac.id
}

Edy YULIANTO

Brawijaya University, Faculty of Administration Science, MT. Haryono 163, Malang, Indonesia, e-mail: edy_y_fia@ub.ac.id

\begin{abstract}
Citation: Supriono, \& Yulianto, E. (2021). THE EFFECT OF FESTIVAL QUALITY ON REVISIT INTENTION: MEDIATING ROLE OF DESTINATION IMAGE IN JEMBER FASHION CARNAVAL, JEMBER, INDONESIA. GeoJournal of Tourism and Geosites, 38(4), 1195-1202. https://doi.org/10.30892/gtg.38426-760
\end{abstract}

\begin{abstract}
This study aims to investigate and explain festival qualities that are applied to festival organizers that affect the destination image and the tourist revisit intention. This research uses a quantitative approach through stati stical analysis of PLS-SEM and distributed questionnaires that have been designed to 200 tourists. The findings of this study indicate that the constructs of the variables that shape the quality of the festival, namely program content, convenience, and staff, have a positive and significant effect on the image of the destination. In addition, the relationship between destination image and revisit intention has a positive and significant effect.
\end{abstract}

Key words: festival quality, destination image, event management of tourism

\section{INTRODUCTION}

Festival quality has been investigated and discussed by Crompton and Love (1995) and Baker and Crompton (2000) who analyzed the relationship between quality, satisfaction, and attractiveness to tourists. In this reg ard, Lee et al (2008) introduced the concept of the festival landscape, which means the general atmosphere experienced by festival visitors to emphasize a holistic experience. Since then, new discussions on event tourism research that focus on festival reconstruction have developed, focusing more on shifting from a materialistic perspective to an immaterial perspective identified related to the main dimensions of festival quality (Oakes and North, 2008; Mason and Paggiaro, 2012; Quintal et al., 2015; Bruwer, 2014; Chang et al., 2014). However, this study is not focused on discussing experiences, behavioral intention, or tourist loyalty to visit as in most other studies. This research is more on destination marketing such as destination image, more specifically, the influence of festival quality on destination image. An event organized by such a host city helps increase tourism opportunities that can enhance the destination image of the area (Getz, 1989; Moon and Han, 2019). Even today, many local governments recognize the advantages of hosting an event that will have a high impact on society (Moon and Han, 2019). The implementation of such event tourism is often used as a means to improve the image of regional tourist destinations and the region itself (Getz, 2016a). Therefore, it is important for the local population to clearly understand the value of organizing this event. In the field of destination marketing, experts have found that event tourism can generate a number of sociological and economic benefits (such as increasing employment opportunities, and concern for the image of an area) (Allen et al., 2002).

In the context of tourism, destination image is closely related to the experience of tourists in these destinations and tourists' perceptions of these destinations. When tourists are satisfied with visiting with the quality of the overall experience such as the event quality attribute, tourists tend to have a positive attitude towards a destination and intend to revisit that destination (Loureiro, 2014). Thus, how tourists perceive the attributes or quality of a destination can affect the image of the destination (Chiu et al., 2014). Therefore, the overall destination image built on the tourist experience can be positively associated with tourists' perceptions of the quality and value of the tourism experience.

Destination image also closely related to tourist satisfaction, which in turn influences the intention of tourists to revisit and recommend the destination (Liu et al., 2017; Prayag et al., 2017). In line with empirical evidence in previous research, it has shown that destination image has a positive and significant effect on revisit intention (Chen and Funk, 2010; Song et al., 2017; Li et al., 2018; Foster and Sidhartais, 2019; Khan et al., 2019).

This is because the destination image is indeed formed by a number of certain attributes or features that attract tourists, ranging from activities or experiences to unique landscapes (Duarte et al., 2018). So, that tourists have their own perceptions to be able to judge from their visiting experience and when there is a unique value it will form a memorable moment for these tourists who will decide on their revisit intention (Chen and Funk, 2010).

Evidence tourism in Indonesia shows an increasing trend and strategic role in driving the economy. This sector has also become a key factor in encouraging the socio-economic progress of society through exports (foreign exchange), job

\footnotetext{
* Corresponding author
} 
creation, new businesses, and infrastructure development. It can be seen that the tourism sector is the leading sector and one for regional development of a country and increasing welfare (Ministry of Tourism, 2015; 2019). Even the UNWTO predicts a growth trend in the number of world foreign tourists by 3.3 percent annually in the 2010 to 2030 period. These opportunities are very large for Indonesia to be one of the destinations that tourists are interested in. The tourism agenda has been planned in such a way by the Ministry of Tourism to be able to attract foreign tourists who are priority targets. The Ministry of Tourism has set $4 \mathrm{C}$ as the standard for event tourism quality, namely Creative Value, Commercial Value, Communication Value, CEO Commitment (Ministry of Tourism and Creative Economy, 2019). Various event agendas in all regions in Indonesia are proof that event tourism in Indonesia has grown rapidly. So that the government to be able to attract 20 million tourists as a target in 2019 has made a national event agenda. The involvement of the Government of Indonesia is part of a responsive form of potential and is aimed at advancing national tourism so that it can have a big impact on society and the national economy. The following are various events scheduled and selected selectively by the Curatorial Team of the Calendar of Events (CoE) from all events in 34 Provinces. Jember Fashion Carnaval (JFC) that engaged in event tourism through fashion carnival is held annually in Jember Regency, East Java. JFC has become an attraction for international tourists and has become one of the global events. It is a combination of carnival and fashion where the theme of the organization departs from developing issues and also as a response to global issues.

\section{LITERATURE REVIEW}

\section{Festival Quality}

Despite the diversity and evolution of the festival, Getz and Page (2016a,) describe it in a very simple way as "a themed public celebration", highlighting the festival's ability to provide cultural opportunities and fun beyond the everyday experience. Festivals provide a way for communities to celebrate their unique cultural traditions and values and can attract local tourists and visitors. Festivals are under a type of event tourism, where people travel to a destination to attend certain events (Getz, 2008). Festivals and other cultural celebrations are less dependent on facilities and may make use of parks, roads, theaters, concert halls and all other public or private places (Getz and Page, 2016a). Thus, festivals are a type of tourism event that is currently in great demand and organized, and has even been designated as a tourism agenda in the country, one of which is Indonesia which is coordinated by the Ministry of Tourism and Creative Economy (2019). Research on festivals is increasing rapidly (Vesci and Botti, 2019; Quintal et al., 2015; Davis, 2016; Yoon et al., 2010; Gannon et al., 2019; Tanford and Jung, 2017) with their respective characteristics and adoption of different attributes.

Many of research on festival quality will refer to Crompton and Love (1995) and Baker and Crompton (2000) which have discussed event tourism and festival quality. This festival quality is an important aspect in building event quality that will influence tourists' perceptions (Vesci and Botti, 2019). More interestingly, a festival that has implemented quality programs, services provided, and adequate facilities will be able to influence the psychological side of tourists during their visit (Ajzen, 2002; Ajzen et al., 2007; Getz, 2008; Girish and Chen, 2017). Based on the experience gained by these tourists, this destination will identify as a must-visit tour. So that there is a relationship between tourist visits and festival quality which affects the destination image (Getz, 2016a). However, not many have researched festival quality on destination image, only a few studies have examined this scope (Folgado-Fernández et al., 2019; Duarte et al., 2018; Hsu and Scott, 2020; Matic et al., 2020). Because of its important role in interpreting the relationship between humans and the festival landscape, attachment to festival quality has been applied in the tourism sector for destination management, marketing, and tourist behavior (Tsai, 2012). Matic et al (2020) explained that destination image is influenced by the experience of tourists, which later on from this experience can be shared through the presence of word of mouth and other types of communication. In line with Hsu and Scott (2020), it shows that experiences can involve tourists in travel destinations, create positive emotions and values, strengthen the bond between tourists and destinations, and influence the image of the visitor's destination. Meanwhile, the quality festival will form a brand of events that have an important function in tourist attractions and help create or develop regional images through related experiences and emotions, which can have a positive relationship with the image of the place (Folgado-Fernández et al., 2019). Based on some of the literature, this study has the following hypothesis:

\section{H1: Program Content has positive and significant influence on Destination Image \\ H2: Facilities Quality has positive and significant influence on Destination Image \\ H3: Compatibility has positive and significant influence on Destination Image \\ H4: Information Quality has positive and significant influence on Destination Image \\ H5: Staff has positive and significant influence on Destination Image}

\section{Destination Image}

Destination image has been studied and discussed in many literatures related to tourism and destination marketing. Many say that destination images are formed fundamentally through individual mental representations of knowledge, feelings, and overall perceptions of certain goals (Baloglu and McCleary, 1999). Meanwhile, Lew (1987) stated that the destination image is formed by a number of certain attributes or features that attract tourists, ranging from activities or experiences to unique landscapes. Thus, the perception of tourists about the festival related to tourism resources becomes a permanent thing from a certain location (eg, monuments, hotels, restaurants, or entertainment) which affects the overall destination image. Therefore, visitors to the host's destination are confident that they will find certain attributes for the destination image (San Martin and Rodríguez del Bosque, 2008). However, destination images are dynamic and change 
when new information is received (Gilbert and Hancock, 2006). According to Gunn (1988), a tourist visit to a destination will change the image of the place. Likewise, Fakeye and Crompton (1991) show that tourists develop a more complex image of a place during travel through the contacts and activities that are in it. Visitors who have the authority to repeat themselves form a more positive destination image (Konecnik and Ruzzier, 2006). Modification of the destination image is an ongoing process and the image will develop due to incidents that occur during the trip (Smith et al., 2015). The concept of destination image has significant value in explaining behavior such as destination selection, intention to revisit and satisfaction (Stylos et al., 2016) as well as developing destination marketing strategies (Tasci et al., 2007).

The shape of the importance of a destination image is described through the attributes it contains and reflects the value identity of the destination (Chew and Jahari, 2014; Comas and Moscardo, 2005). Destination image is an important factor that influences the choice of tourist destinations. Cognitive and affective aspects form the two main components of the destination image (Crompton, 1979). Cognitive image refers to tourists' beliefs about destination attributes, while affective image refers to how tourists feel about the destination (Li et al., 2018; Loureiro and Jesus, 2019). In line with that, Chew and Jahari (2014) added that cognitive imagery refers to beliefs and knowledge about the attributes of a travel destination, and affective imagery refers to emotions or feelings attached to the destination. Previous research tends to focus more on destination image antecedents which refer to tourist characteristics (eg, psychological, social) and stimulus factors (eg, information sources, previous visiting experiences.

This study will discuss empirical results related to destination image items with revisit intention. This is also in line with several studies which show that destination image has a positive and significant influence on revisit intention (Borges et al., 2020; Li et al., 2018; Chew and Jahari, 2014; Loureiro and Jesus, 2019; Song et al., 2017; Matic et al., 2020) Especially in the context of event tourism, where the quality festival attributes in which there is a festival landscape can shape the psychological aspects of tourists and affect behavioral intention to revisit intention. In this condition, destination image will certainly have a positive effect on revisit intention, so to the researcher. This hypothesis is based on the literature explaining destination image and revisit intention, as shown below:

\section{H6: Destination Image has positive and significant influence on Revisit Intention}

\section{Revisit Intention}

Theory of Reasoned Action put forward by Ajzen and Fishbein (1975) explains that tourists' decisions in visiting are shaped by intention. Ajzen et al. (1980) assume that intention is the single most important predictor of human behavior, and that humans have rationality in using available information systematically. The model from Ajzen and Fishbein (1975) was originally developed and deals with predicting intentions to take sensible actions in life experiences, such as visiting intentions and experiences at tourist destinations. So in the discussion of revisit intention, before tourists decide to visit again, there must be a behavioral intention to visit so that they will have a visiting experience to determine whether tourists make a return visit (Baker and Crompton, 2000). Furthermore, revisit intention refers to the possibility of revisiting or revisiting the destinations that have been visited (Baker and Crompton, 2000). Meleddu et al. (2015) in their study focused on the antecedents of revisit intention to find out the reasons why tourists would prefer to revisit the same destination. Several studies have stated that previous experiences can influence tourists to visit again (Chang, 2013; Kim et al., 2015). However, Lee at al. (2014) has different findings, namely by identifying three motivational factors that influence the intention to visit again, which are called 'ego-defensive function', 'utilitarian function-selfdevelopment', and 'utilitarian function-reward'. Although some of these studies show different results, Vesci and Botti (2019) argue that the satisfaction and value suitability desired when visiting for the first time are strong reasons that can be explained. Thus, actually these studies can be said to be appropriate but with different results on the perceptions of tourists. Because the psychological aspect of tourists is fundamental to knowing and influencing the experience and satisfaction side so that it can be made a decision to make a revisit intention (Ajzen, 2002; Ajzen et al., 2007).

\section{METHOD AND ANALYSIS}

This study uses a quantitative approach and distribute questionnaires to tourists visiting Jember Fashion Carnaval from various respective regions with a total sample of 200 tourists. In this study, it was used the PLS-SEM statistical analysis with a causal modeling approach and aimed at maximizing the explained variance of the dependent latent constructs (Hair et al., 2014; Hair et al., 2019). In this study, it was used the descriptive statistical analysis to determine the respondent's demographic frequency and the area of origin of tourists. This result showed that the most dominant gender of respondents is female $(n=115,57.5 \%)$ and for male $(n=85,42.5 \%)$. Meanwhile, of all respondents, the most dominant age ranges were 21-25 years old $(n=70,35 \%)$ and $26-30$ years old $(n=54,27 \%)$. In addition, the frequency of visits is dominated by tourists from the area of origin, namely Jember Regency with more than five times $(\mathrm{n}=63$, $31.5 \%$ ) visiting the Jember Fashion Carnaval festival. Regarding the measurement of validity and reliability in this study, it was known in the results of the analysis by PLS-SEM. Hair (2014) argued that composite reliability and cronbach's $\alpha$ determine reliability, then for all of items should be greater than 0.70 . In this study all of variable possess high composite reliability and cronbach's $\alpha$ value more than 0.8 . All of these values were considered to be acceptable and confirm an adequate reliability. To ensure validity indicates that a set of indicators represents the same underlying construct, which can be demonstrated through their unidimensionality. The validity of the discriminant variables was proven by calculating the average value of extraction (AVE) and value obtained between variables. Namely, AVE value for all of variable was greater than 0.5, indicating that variable is sufficient convergent validity (Hair, 2019). 
Further, each of the variables were measured and possess value more than 0.6. That AVE is a measure of communality for each latent variable (Hair, 2019) and indicated adequate result as all of the variance show exhibit value above 0.50 respectively. Thus, the construct measurements of this research are indicated to be robust.

The results of hypothesis testing on PLS-SEM determine the model-fit and path coefficients as the quantities used in determining the overall relationship effect in the model. Regarding sequential partial models were determined for running the statistical analysis. Thus, first hypothesis, the effect of program content was tested with destination image and resulting in coefficient of determination $\left(\mathrm{R}^{2}\right)$ of 0.602 . Then, it was determined the relationship between program content on destination image has shown positive and significant effect $(\mathrm{PC}=0.308$, p-value $<0.05)$ and hence $\mathrm{H} 1$ was accepted. Second hypothesis facilities quality on destination image was tested and the result showed that it was not significant $(\mathrm{FQ}=0.032$, p-value>0.05) to conclude $\mathrm{H} 2$ was rejected. Whereas the third hypothesis gives results on the relationship between

Table 1. Statistical Effect and Hypotheses Testing

\begin{tabular}{|c|c|c|c|c|c|}
\hline Variable & $\begin{array}{c}\text { Direct } \\
\text { Effect }(囚)\end{array}$ & $\begin{array}{c}\text { Indirect } \\
\text { Effect (B) }\end{array}$ & \begin{tabular}{|c}
$T$ \\
Score
\end{tabular} & \begin{tabular}{|c|}
$P$ \\
Values
\end{tabular} & Conclusion \\
\hline $\mathrm{PC} \rightarrow \mathrm{DI}$ & 0.308 & & 2.522 & 0.012 & Accepted \\
\hline $\mathrm{FQ} \rightarrow \mathrm{DI}$ & 0.032 & & 0.336 & 0.737 & Rejected \\
\hline $\mathrm{C} \rightarrow \mathrm{DI}$ & 0.313 & & 2.349 & 0.015 & Accepted \\
\hline IQ $\rightarrow$ DI & 0.179 & & 1.308 & 0.192 & Rejected \\
\hline $\mathrm{S} \rightarrow \mathrm{DI}$ & 0.597 & & 5.316 & 0.000 & Accepted \\
\hline $\mathrm{DI} \rightarrow \mathrm{RI}$ & 0.756 & & 14.478 & 0.000 & Accepted \\
\hline $\mathrm{PC} \rightarrow \mathrm{DI} \rightarrow \mathrm{RI}$ & & 0.232 & 2.454 & 0.014 & Accepted \\
\hline $\mathrm{FQ} \rightarrow \mathrm{DI} \rightarrow \mathrm{RI}$ & & 0.024 & 0.336 & 0.737 & Rejected \\
\hline $\mathrm{C} \rightarrow \mathrm{DI} \rightarrow \mathrm{RI}$ & & 0.236 & 2.476 & 0.014 & Accepted \\
\hline $\mathrm{IQ} \rightarrow \mathrm{DI} \rightarrow \mathrm{RI}$ & & 0.135 & 1.311 & 0.190 & Rejected \\
\hline $\mathrm{S} \rightarrow$ DI RI & & 0.451 & 4.845 & 0.000 & Accepted \\
\hline
\end{tabular}

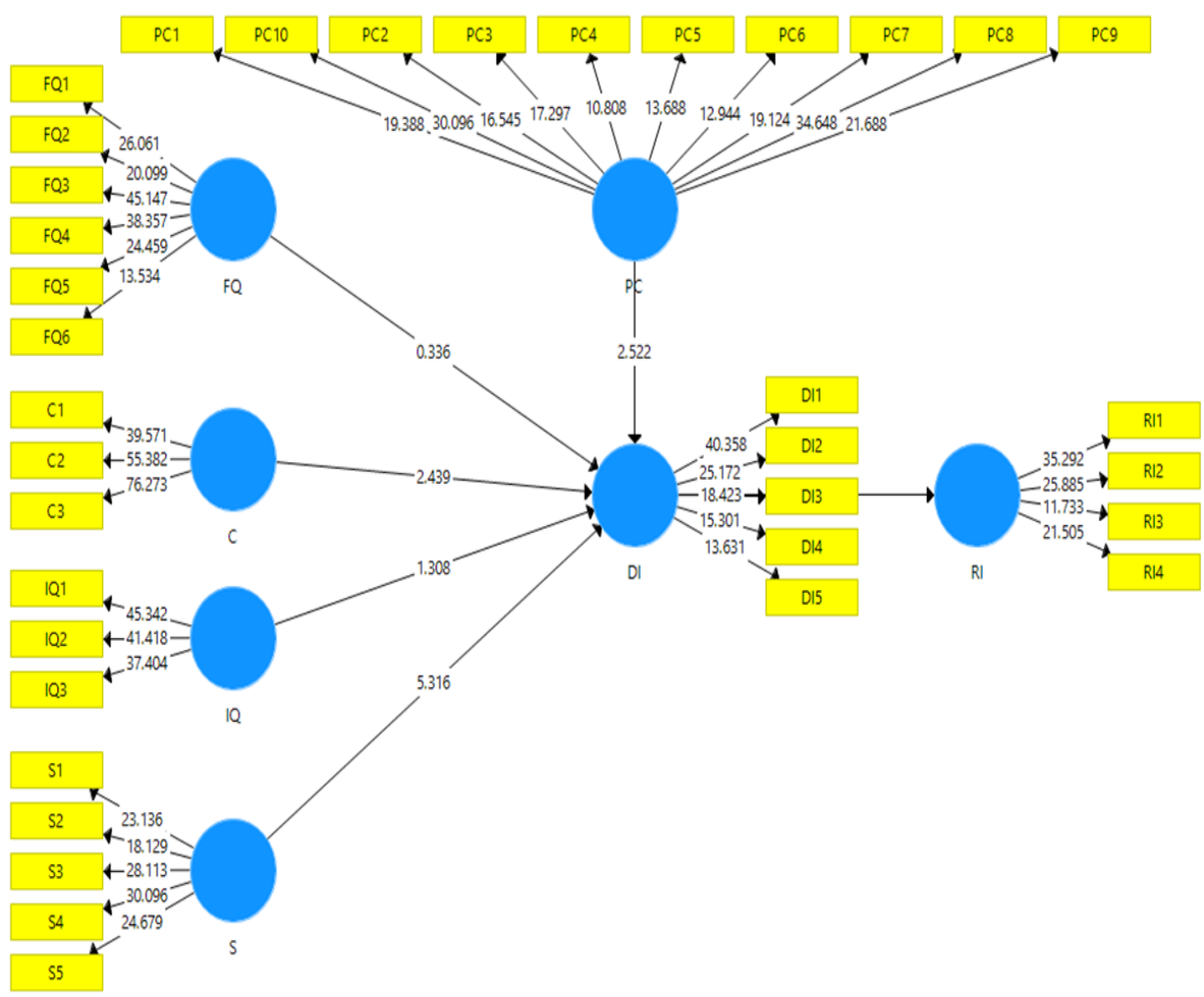

Figure 1. Structural Model Output convenience and destination image and showed that it has a positive and significant effect $(\mathrm{C}=0.313$, $\mathrm{p}$-value $<0.05)$, so $\mathrm{H} 3$ can be accepted. In addition, the fourth hypothesis showed the results that information quality on destination image has not significant effect $(\mathrm{IQ}=0.179$, p-value $>0.05$ ), so H4 is rejected. Fifth hypothesis was showed in the effect of relationship between staff on destination image has positive and significant effect $(S=0.121$, p-value $<0.05$ ), so that H5 accepted. Meanwhile, the results of testing the relationship between destination image on revisit intention $\left(\mathrm{R}^{2}=0.571\right)$ showed a positive and significant effect ( $\mathrm{DI}=0.756$, p-value $<0.05)$, then $\mathrm{H} 6$ is accepted. Table 3 also presents the mediating role of destination image from program content, facilities quality, convenience, information quality, and staff towards revisit intention, the implications of which will also be discussed.

FINDING AND DISCUSSION Based on the results of hypothesis testing in table 3 it has indicated that the program content has a positive and significant effect on the destination image, it is the first hypothesis. It is true that the content program is a dominant influence for tourist attraction because it will provide performances that are of interest to tourists (Lee et al., 2008). With the Content Program which attracts tourists, it will form a landscape festival for the selling power of festival organizers to tourists (Vesci and Botti, 2019; Quintal et al., 2015). Interestingly, the Jember Fashion Carnaval (JFC) always provides a suitable content theme every year that describes and is a form of response to certain events in the surrounding environment, both regionally, nationally, and even internationally.

According to Tanford and Jung (2017), festival organizers must be more responsive in creating a theme so that tourists make repeat visits. This is of course for the sake of sustainability and sustainability of organizing the festival (Getz, 2013; Getz and Page, 2016a). The content program provided by the organizer will shape the atmosphere of the festival and can be interpreted as the value of the festival which includes most of the services offered at the festival, consistent with what has been reported by existing literature (Lee et al., 2008; Davis, 2016; Yoon et al., 2010; Gannon et al., 2019; Vesci and Botti, 2019). These findings confirm that each festival uniquely produces its own characteristics and quality dimensions based on the main theme or product offering (Folgado-Fernández et al., 2019). In addition, Tanford and Jung (2017) explain again about the existence of festivals as a destination image, planners must focus on providing programs and activities that 
visitors enjoy. Then the festival must have a unique theme, the thematic content must be high quality. For instance, cultural festivals often feature original costumes and local products, the concept is in tune with those held by the Jember Fashion Carnaval. The festival is usually held in a temporary venue whose environment is created by the organizer (Getz and Page, 2016b). Similarly from this findings, previous researchers showed that festival quality influence was positive and significant on destination image (Kim, 2018; Wong et al., 2018; Duarte et al., 2018; Folgado-Fernández et al., 2019).

Meanwhile, regarding the results of the second hypothesis they show that facilities quality influence is not significant to the destination image. It is widely accepted that the festival offers many tangible and intangible benefits to the host community (Fourie and Santana-Gallego, 2011). Research by Moon et al (2013) suggests that when holding a festival, organizers must prioritize the quality of service to satisfy the audience, sponsors, and local residents through the facilities provided. According to Getz and Page (2016a; 2016b), facility availability is best defined as a visitor's overall impression of the relative inferiority / superiority of the organization and its services.

High facilities quality is now recognized as a means of ensuring future success by many event organizers and in the event management literature (Getz, 2013; Getz and Page, 2016a; Vesci and Botti, 2019). In other words, visitors perceive an event as positive or valuable because of tangible (e.g. design, equipment, ambience and parking) or intangible (e.g. reliability, security, communication and assurance), visitors may stay at the event longer, then buy souvenirs or recommend them to others via social media (Jeong and Kim, 2019). Although, local festivals have sprung up with the special purpose of celebrating local culinary traditions, building business and trade in local products, and fostering domestic and regional tourism, it is better if local festivals need to focus on the characteristics of core services, namely quality facilities (Vesci and Botti, 2019). Although, Getz and Page (2016a) stated that actually a performance festival does not require a lot of resources (for example, buildings, decorations), Lee et al. (2008) still pay attention to the landscape festival because it will create a comfortable atmosphere for visitors. In fact, some experts (Baker and Crompton, 2000; Crompton, 1979) have observed that festivals play an important role in the development of many regions and in the implementation of branding strategies. In line with Getz and Page (2016a), Gursoy et al (2004) stated that festivals do not depend on expensive physical development and instead exploit existing infrastructure, besides that, they do not require large capital investments (for example, building a theatre).

In relation to festival quality, the results of the third hypothesis test which explains convenience have a positive and significant effect on destination image. Thus, the Jember Fashion Carnaval festival has paid attention to convenience in conceptualizing and designing when holding events. Because indeed convenience plays an important role in shaping the perceived value of event tourism visitors as explained by García-Fernández et al. (2018).

As also Lee et al (2008) who have introduced festivalscape, convenience is an attribute to establish festival quality. Furthermore, Lee et al (2008) have clarified that festivalscape includes many features, and features that are tangible affect visitor attitudes and behavior. In fact, although the festivalscape is composed of many cues, the importance, relevance, and perception of certain dimensions can vary between spaces (Davis, 2016; Quintal et al., 2015). Consequently, the scene of the festival itself also appears to be context dependent as shown in Vesci and Botti's (2019) research. Investigating a small local festival held by the city that focuses on the history and culture of the city, Anil (2012) concluded that food, festival area (including events in the festival), and convenience are the only three factors that significantly affect tourist / visitor satisfaction. In the context of heritage tourism, research by Remoaldo et al (2014) reveals the perceived attributes of heritage destinations that include historical background and functionality, shopping and entertainment, convenience, and efficiency. However, the festival cape measurement framework proposed in the literature, although adapted to different contexts, was adapted to the characteristics of the festival.

Meanwhile, in relation to destination image, convenience is also an attribute in it in many literatures that discuss destination image (Comas and Moscardo, 2005; Chew and Jahari, 2014; Borges et al., 2020; Li et al., 2018). Destination image is an important factor influencing the choice of tourist destinations through cognitive and affective aspects which form the two main components of destination image (Crompton, 1979). Cognitive image refers to tourists 'beliefs about destination attributes, while affective image refers to tourists' feelings towards a destination that can be influenced by convenience (Li et al., 2018; Loureiro and Jesus, 2019; Davis, 2016; Quintal et al., 2015; Lee et al., 2008).

The results of testing the fourth hypothesis indicate that information quality has no significant effect on destination image. Meanwhile, from the perspective of festival quality attributes that have been described and discussed by Crompton and Love (1995), information becomes a forming attribute. In the next discussion, information becomes a meaningful assessment of the festival quality attributes (Baker and Crompton, 2000). The references developed on these attributes have been used in research that discusses festival quality (Folgado-Fernández et al., 2019; Duarte et al., 2018; Hsu and Scott, 2020; Matic et al., 2020). As a form of providing service communication, information quality is needed to provide information to visitors when traveling, because through this information it becomes knowledge for visitors to decide on destination choices (Quintal et al., 2015). Meanwhile in the current era with advances in information technology via the internet, visitors take advantage and use the power of social media (for example, Instagram, websites, search engines) to find information on tourist destinations (Jeong and Kim, 2019). Therefore, information is very important to provide knowledge to visitors, such as in the context of tourist destinations which are useful in knowing the timing of the implementation and other values being sought (Habibi et al., 2014; Zeng and Gerritsen, 2014). Meanwhile, information can be an important part of avoiding confusion of knowledge and discrepancies in the values shared by the organizers. Lee et al (2008) even emphasized information as an attribute in shaping festivalscape. In addition, it will be related to destination marketing, information quality as a means of promotion to improve the image of a destination (Jeong and Kim, 2019). Furthermore, the communicative scope of the festival can be conceptualized as the adequacy 
and clarity of the information tools adopted to guide tourists to the proper service realization, thereby depicting the role of tourists and transmitting the desired image intended by festival organizers (Vesci and Botti, 2019). Thus, information is the scope of communication for organizers to share the value created and distributed to tourists (Quintal et al., 2015).

Staff service is an important issue to analyze in terms of its effect on visitor attitudes and behavioral intentions. In accordance with this, the results of testing the fifth hypothesis, namely staff have a positive and significant effect on the destination image. Festivals generally have a low level of professionalism in relation to staff, because they often involve volunteers (Hsu and Scott, 2020). Thus, the success of a festival depends on the enthusiasm and actions of these volunteers, who are involved in various activities, such as services to visitors and their availability in guiding visitors (Anil, 2012; Tsai, 2012). Service staffing forms include the level of politeness and knowledge of service providers, both of which are necessary for successful interaction with visitors (Yoon et al., 2010; Gannon et al., 2019). Quintal et al (2015) found that the staff dimension of the festivalscape was one of the most influential factors in influencing tourist attitudes. Vesci and Botti (2019) also explained in their research that service interactions (relational features of staff) have a positive and significant effect on perceptions of destination images so that visitors will have a good experience and feel satisfied. Good service interactions and adequate staff behavior occupy an important position in determining tourist attitudes towards revisited festivals (Matic et al., 2020). However, the influence of staff and information service interactions has not always been confirmed in the previous literature (Lee et al., 2008; Yoon et al., 2010) reinforcing the assumption that festival types and types of settings can significantly change visitor behavior. The relevance of staff interactions in the context of festivals is likely to be determined by the interactive dimension specifically motivating domestic tourists who are the target of this type of event (Duarte et al., 2018; Matic et al., 2020). Thus, emphasizing the need for festival managers to provide sufficient information that directs people to the festival area, and must ensure the provision of quality service through the availability of polite and knowledgeable staff (Tsai, 2012; Hsu and Scott, 2020). Special attention should be paid to providing staff with adequate training in essential skills as staff service is an important part, such as communication, courtesy and kindness (Folgado-Fernández et al., 2019).

Finally, discussed and implication about influence of destination image on tourist revisit intention has positif and significant impact. Destination as the destination of a tourist trip will consider the destination image (Boo and Busser, 2005). Tourists in deciding to visit again are influenced by visiting experiences where this image has been embedded in their mind (Khan et al., 2019; Li et al., 2018). Given that festival products and services are considered experiential and because experience itself can be an important factor influencing participants' satisfaction and intention to revisit the destination, it is very important to understand the values of festival participants in the visiting experience (Moon and Han, 2019; San Martín and Rodríguez del Bosque, 2008; Song et al., 2017). In addition, assuming that satisfaction is consumers 'overall evaluation of the total consumer experience, understanding of consumers' experiences, and their perceived value from products or services becomes more important than ever in the context of tourism and hospitality (Smith et al., 2015; Tasci et al., 2007). Referring to Holbrook (1994) categorizes experience value into four different groups, consumer return on investment, service excellence, aesthetic and escapism, which are also categorized as activity dimensions, such as active or reactive consumer value. In addition, some researchers focus on consumer reasons as determined by experiential-oriented or goal-oriented cognition in a particular environment (Stylos et al., 2016). Thus, there are strong reasons why festivalscape should be considered by festival organizers as forming visitors' experiences and perceptions of the destination image (Lee et al., 2008; Vesci and Botti, 2019; Quintal et al., 2015). Thus, tourist satisfaction affects the level of perception on the destination image, with this the tourists will decide to visit again. Related to this findings with previous research that had explained (Chang, 2013; Kim et al., 2015; Remoaldo et al., 2014; Foster and Sidhartais, 2019; Kim, 2018; Loureiro and Jesus, 2019; Wong et al., 2019).

\section{CONCLUSION AND LIMITATION}

This research is the background of the existence of a local festival that has been moving for a long time and has become an international class festival which has had a big impact on the local community. Interestingly, Jember Fashion Carnaval has become an icon for the host city and has become an attraction for both domestic and foreign tourists. Thus, this research underlies the concept of event management developed by Getz and Page (2016a) which explains how to manage and design the concept of sustainable event tourism. Thus, this study adopts the festival quality construct to assess the existing concepts that are currently being implemented that will affect the destination image and tourist revisit intention. The quantitative approach is used in this study and utilizes PLS-SEM statistical analysis to explain the path analysis. Regarding the results of this study that have been explained and discussed, but there is limitation, so future research may be necessary to add a variable construct of perceived value and tourist knowledge which can be considered as the influence of the decision to revisit intention on tourism events.

\section{REFERENCES}

Ajzen, I. (2002). Residual effects of past on later behavior: Habituation and reasoned action perspectives. Personality and Social Psychology Review, 6(2), 107-122. https://doi.org/10.1207/S15327957PSPR0602_02

Ajzen, I., Albarracin, D., \& Hornik, R. (2007). Prediction and change of health behavior: Applying the reasoned action approach. Psychology Press. Ajzen, I., Heilbroner, L.R., Fishbein, M., \& Thurow, C.L. (1980). Understanding Attitudes and Predicting Social Behavior. Prentice-Hall. Ajzen, I., \& Fishbein, M. (1975). A Bayesian analysis of attribution processes. Psychological bulletin, 82(2), 261. https://doi.org/10.1037/h0076477 Allen, J., O'toole, W., Harris, R., \& McDonnell, I. (2008). Festival and special event management. Wiley.

Anil, N.K. (2012). Festival visitors' satisfaction and loyalty: An example of small, local, and municipality organized festival. Tourism: An International Interdisciplinary Journal, 60(3), 255-271. https://hrcak.srce.hr/93004 
Baker, D.A., \& Crompton, J.L. (2000). Quality, satisfaction and behavioral intentions. Annals of tourism research, 27(3), 785-804. https://doi.org/10.1016/S0160-7383(99)00108-5

Baloglu, S., \& McCleary, K.W. (1999). A model of destination image formation. Annals of Tourism Research, 26(4), 868-897. https://doi.org/10.1016/S0160-7383(99)00030-4

Boo, S., \& Busser, J.A. (2005). Impact analysis of a tourism festival on tourists destination images. Event Management, 9(4), 223237.https://doi.org/10.3727/152599506776771562

Borges, A.P., Cunha, C., \& Lopes, J. (2020). The main factors that determine the intention to revisit a music festival. Journal of Policy Research in Tourism, Leisure and Events, 1-22. https://doi.org/10.1080/19407963.2020.1817051

Bruwer, J. (2014). Service quality perception and satisfaction: Buying behaviour prediction in an Australian Festivalscape. International Journal of Tourism Research, 16(1), 76-86. https://doi.org/10.1002/jtr.1901

Chang, S., Gibson, H., \& Sisson, L. (2014). The loyalty process of residents and tourists in the festival context. Current Issues in Tourism, 17(9), 783-799. https://doi.org/10.1080/13683500.2013.768214

Chen, N., \& Funk, D.C. (2010). Exploring destination image, experience and revisit intention: A comparison of sport and non-sport tourist perceptions. Journal of Sport \& Tourism, 15(3), 239-259. https://doi.org/10.1080/14775085.2010.513148

Chew, E.Y.T., \& Jahari, S.A. (2014). Destination image as a mediator between perceived risks and revisit intention: A case of postdisaster Japan. Tourism Management, 40, 382-393. https://doi.org/10.1016/j.tourman.2013.07.008

Chiu, Y.T. H., Lee, W.I., \& Chen, T.H. (2014). Environmentally responsible behavior in ecotourism: Exploring the role of destination image and value perception. Asia Pacific Journal of Tourism Research, 19(8), 876-889. https://doi.org/10.1080/10941665.2013.818048

Comas, M., \& Moscardo, G. (2005). Understanding associations and their conference decision-making processes. In Journal of Convention \& Event Tourism (Vol. 7, No. 3-4, pp. 117-138). Taylor \& Francis Group. https://doi.org/10.1300/J452v07n03_07

Crompton, J.L. (1979). An assessment of the image of Mexico as a vacation destination and the influence of geographical location upon that image. Journal of Travel Research, 17(4), 18-23.https://doi.org/10.1300/J452v07n03_07

Crompton, J.L., \& Love, L.L. (1995). The predictive validity of alternative approaches to evaluating quality of a festival. Journal of travel research, 34(1), 11-24. https://doi.org/10.1177/004728759503400102

Davis, A. (2016). Experiential places or places of experience? Place identity and place attachment as mechanisms for creating festival environment. Tourism management, 55, 49-61. https://doi.org/10.1016/j.tourman.2016.01.006

Duarte, P., Folgado-Fernández, J.A., \& Hernández-Mogollón, J.M. (2018). Measurement of the impact of music festivals on destination image: the case of a womad festival. Event Management, 22(4), 517-526. https://doi.org/10.3727/152599518X15264726192451

Fakeye, P.C., \& Crompton, J.L. (1991). Image differences between prospective, first-time, and repeat visitors to the Lower Rio Grande Valley. Journal of Travel Research, 30(2), 10-16. https://doi.org/10.1177/004728759103000202

Folgado-Fernández, J.A., Hernández-Mogollón, J.M., \& Duarte, P. (2017). Destination image and loyalty development: the impact of tourists' food experiences at gastronomic events. Scandinavian Journal of Hospitality and Tourism, 17(1), 92-110. https://doi.org/10. $1080 / 15022250.2016 .1221181$

Foster, B., \& Sidhartais, I. (2019). A Perspective from Indonesian tourists: the influence of destination image on revisit intention. Journal of Applied Business Research (JABR), 35(1), 29-34. https://doi.org/10.19030/jabr.v35i1.10295

Fourie, J., \& Santana-Gallego, M. (2011). The impact of mega-sport events on tourist arrivals. Tourism management, 32(6), 1364-1370. https://doi.org/10.1016/j.tourman.2011.01.011

Gannon, M., Taheri, B., \& Olya, H. (2019). Festival quality, self-connection, and bragging. Annals of Tourism Research, 76, $239-252$. https://doi.org/10.1016/j.annals.2019.04.014

García-Fernández, J., Gálvez-Ruíz, P., Fernández-Gavira, J., Vélez-Colón, L., Pitts, B., \& Bernal-García, A. (2018). The effects of service convenience and perceived quality on perceived value, satisfaction and loyalty in low-cost fitness centers. Sport Management Review, 21(3), 250-262.https://doi.org/10.1016/j.smr.2017.07.003

Getz, D. (1989). Special events: Defining the product. Tourism management, 10(2), 125-137. https://doi.org/10.1016/0261-5177(89)90053-8

Getz, D. (2008). Event tourism: Definition, evolution, and research. Tourism management, 29(3), 403-428. https://doi.org/10. 1016/j.tourman.2007.07.017

Getz, D. (2013). Event tourism: concepts, international case studies, and research. Cognizant Communication Corporation.

Getz, D., \& Page, S.J. (2016a). Event studies: Theory, research and policy for planned events. Routledge.

Getz, D., \& Page, S.J. (2016b). Progress and prospects for event tourism research. Tourism management, 52, 593-631. https://doi.org/10. 1016/j.tourman.2015.03.007

Gilbert, D., \& Hancock, C. (2006). New York City and the transatlantic imagination: French and English tourism and the spectacle of the modern metropolis, 1893-1939. Journal of Urban History, 33(1), 77-107. https://doi.org/10.1177/0096144206290385

Girish, V.G., \& Chen, C.F. (2017). Authenticity, experience, and loyalty in the festival context: Evidence from the San Fermin festival, Spain. Current Issues in Tourism, 20(15), 1551-1556. https://doi.org/10.1080/13683500.2017.1296821

Gunn, C. (1988). Vacationscapes: Designing tourist regions. Second Edition, 1988, 208 pages. Van Nostrand Reinhold, New York.

Gursoy, D., Kim, K., \& Uysal, M. (2004). Perceived impacts of festivals and special events by organizers: an extension and validation. Tourism management, 25(2), 171-181. https://doi.org/10.1016/S0261-5177(03)00092-X

Habibi, M.R., Laroche, M., \& Richard, M.O. (2014). The roles of brand community and community engagement in building brand trust on social media. Computers in human behavior, 37, 152-161. https://doi.org/10.1016/j.chb.2014.04.016

Hair, J.F., Ringle, C.M., \& Sarstedt, M. (2014). Partial least squares structural equation modeling: Rigorous applications, better results and higher acceptance. Long range planning, 46(1-2), 1-12. https://doi.org/10.1016/j.lrp.2013.01.001

Hair, J.F., Sarstedt, M., \& Ringle, C.M. (2019). Rethinking some of the rethinking of partial least squares. European Journal of Marketing, 53(4), 566-584.

Helfat, C.E., \& Peteraf, M.A. (2003). The dynamic resource-based view: Capability lifecycles. Strategic Management Journal, 24(10), 997-1010. https://doi.org/10.1108/EJM-10-2018-0665

Holbrook, M.B. (1994). The nature of customer value: an axiology of services in the consumption experience. Service quality: New directions in theory and practice, 21(1), 21-71. http://dx.doi.org/10.4135/9781452229102.n2

Hsu, F.C., \& Scott, N. (2020). Food experience, place attachment, destination image and the role of food-related personality traits. Journal of Hospitality and Tourism Management, 44, 79-87. https://doi.org/10.1016/j.jhtm.2020.05.010

Jeong, Y., \& Kim, S. (2019). A study of event quality, destination image, perceived value, tourist satisfaction, and destination loyalty among sport tourists. Asia Pacific Journal of Marketing and Logistics, 32(4), 940-960. https://doi.org/10.1108/APJML-02-2019-0101

Matic, R.M., Karagiorgos, T., Maksimovic, N., Alexandris, K., Bujkovic, R., \& Drid, P. (2020). Testing the influence of destination image and event quality on athletes' intentions to re-visit the city: a case study of the 2017. World youth and juniors' sambo championships in Novi Sad, Serbia. Managing Sport and Leisure, 25(5), 390-401. https://doi.org/10.1080/23750472.2020.1724187 
Khan, J., Maltezou, V., \& He, C. (2019). The role of destination brand image and revisit intention on tourist spending. Strategic Innovative Marketing and Tourism. 7th ICSIMAT, Athenian Riviera, Greece, 2018 (pp. 371-376). Springer, Cham. https://doi.org/10.1007/978-3-030-12453-3_42

Kim, J.H. (2018). The impact of memorable tourism experiences on loyalty behaviors: The mediating effects of destination image and satisfaction. Journal of Travel Research, 57(7), 856-870. https://doi.org/10.1177/0047287517721369

Konecnik Ruzzier, M., \& Ruzzier, M. (2006). The influence of previous visitation on customer's evaluation of a tourism destination. Managing Global Transitions,4(2), 145-165. https://www.researchgate.net/publication/5173639_The_Influence_of_ Previous_Visitation_on_Customer\%27s_Evaluation_of_a_Tourism_Destination

Lee, B., Lee, C.K., \& Lee, J. (2014). Dynamic nature of destination image and influence of tourist overall satisfaction on image modification. Journal of Travel Research, 53(2), 239-251. https://doi.org/10.1177/0047287513496466

Lee, Y.K., Lee, C.K., Lee, S.K., \& Babin, B.J. (2008). Festivalscapes and patrons' emotions, satisfaction, and loyalty. Journal of Business Research, 61(1), 56-64. https://doi.org/10.1016/j.jbusres.2006.05.009

Lew, A.A. (1987). A framework of tourist attraction research. Annals of Tourism Research, 14(4), 553-575. https://doi.org/10.1177/ 0047287513496466

Li, F., Wen, J., \& Ying, T. (2018). The influence of crisis on tourists' perceived destination image and revisit intention: An exploratory study of Chinese tourists to North Korea. Journal of Destination Marketing \& Management, 9, 104-111. https://doi.org/10.1016/j.jdmm.2017.11.006

Liu, X., Li, J., \& Kim, W.G. (2017). The role of travel experience in the structural relationships among tourists' perceived image, satisfaction, and behavioral intentions. Tourism and Hospitality Research, 17(2), 135-146. https://doi.org/10.1177/1467358415610371

Loureiro, S.M.C. (2014). The role of the rural tourism experience economy in place attachment and behavioral intentions. International Journal of Hospitality Management, 40, 1-9. https://doi.org/10.1016/j.ijhm.2014.02.010

Loureiro, S.M.C., \& Jesus, S. (2019). How perceived risk and animosity towards a destination may influence destination image and intention to revisit: The case of Rio de Janeiro. Anatolia, 30(4), 497-512. https://doi.org/10.1080/13032917.2019.1632910.

Mason, M.C., \& Paggiaro, A. (2012). Investigating the role of festivalscape in culinary tourism: The case of food and wine events. Tourism management, 33(6), 1329-1336. https://doi.org/10.1016/j.tourman.2011.12.016

Meleddu, M., Paci, R., \& Pulina, M. (2015). Repeated behaviour and destination loyalty. Tourism Management, 50, $159-171$. https://doi.org/10.1016/j.tourman.2015.01.032

Moon, H., \& Han, H. (2019). Tourist experience quality and loyalty to an island destination: The moderating impact of destination image. Journal of Travel \& Tourism Marketing, 36(1), 43-59. https://doi.org/10.1080/10548408.2018.1494083

Moon, K.S., Ko, Y.J., Connaughton, D.P., \& Lee, J.H. (2013). A mediating role of destination image in the relationship between event quality, perceived value, and behavioral intention. Journal of Sport \& Tourism, 18(1), 49-66. https://doi.org/10.1080/14775085.2013.799960

Oakes, S., \& North, A.C. (2008). Reviewing congruity effects in the service environment musicscape. International Journal of Service Industry Management, 19 (1), 63-82. https://doi.org/10.1108/09564230810855716

Prayag, G., Hosany, S., Muskat, B., \& Del Chiappa, G. (2017). Understanding the relationships between tourists' emotional experiences, perceived overall image, satisfaction, and intention to recommend. Journal of Travel Research,56(1), 41-54. https://doi.org/10.1177/0047287515620567

Quintal, V.A., Thomas, B., \& Phau, I. (2015). Incorporating the winescape into the theory of planned behaviour: Examining 'new world'wineries. Tourism Management, 46, 596-609. https://doi.org/10.1016/j.tourman.2014.08.013

Remoaldo, P.C., Ribeiro, J.C., Vareiro, L., \& Santos, J.F. (2014). Tourists' perceptions of world heritage destinations: The case of Guimarães (Portugal). Tourism and Hospitality Research, 14(4), 206-218. https://doi.org/10.1177/1467358414541457

San-Martín, H., \& Rodríguez del Bosque, I.A. (2008). Exploring the cognitive-affective nature of destination image and the role of psychological factors in its formation. Tourism Management, 29(2), 263-277. https://doi.org/10.1016/j.tourman.2007.03.012

Song, H.M., Kim, K.S., \& Yim, B.H. (2017). The mediating effect of place attachment on the relationship between golf tourism destination image and revisit intention. Asia Pacific Journal of Tourism Research, 22(11), 1182-1193. https://doi.org/10.1080/ 10941665.2017.1377740

Smith, W.W., Li, X.R., Pan, B., Witte, M., \& Doherty, S.T. (2015). Tracking destination image across the trip experience with smartphone technology. Tourism Management, 48, 113-122. https://doi.org/10.1016/j.tourman.2014.04.010

Stylos, N., Vassiliadis, C.A., Bellou, V., \& Andronikidis, A. (2016). Destination images, holistic images and personal normative beliefs: Predictors of intention to revisit a destination. Tourism Management, 53, 40-60. https://doi.org/10.1016/j.tourman.2015.09.006

Tanford, S., \& Jung, S. (2017). Festival attributes and perceptions: A meta-analysis of relationships with satisfaction and loyalty. Tourism Management, 61, 209-220. https://doi.org/10.1016/j.tourman.2017.02.005

Tasci, A.D., Gartner, W.C., \& Tamer Cavusgil, S. (2007). Conceptualization and operationalization of destination image. Journal of Hospitality \& Tourism Research, 31(2), 194-223. https://doi.org/10.1177/1096348006297290

Tsai, S.P. (2012). Place attachment and tourism marketing: Investigating international tourists in Singapore. International Journal of Tourism Research, 14(2), 139-152. https://doi.org/10.1002/jtr.842

Vesci, M., \& Botti, A. (2019). Festival quality, theory of planned behavior and revisiting intention: Evidence from local and small Italian culinary festivals. Journal of Hospitality and Tourism Management, 38, 5-15. https://doi.org/10.1016/j.jhtm.2018.10.003

Wong, I.A., Xu, Y.H., Tan, X.S., \& Wen, H. (2019). The boundary condition of travel satisfaction and the mediating role of destination image: The case of event tourism. Journal of Vacation Marketing, 25(2), 207-224. https://doi.org/10.1177/1356766718763691

Yoon, Y.S., Lee, J.S., \& Lee, C.K. (2010). Measuring festival quality and value affecting visitors' satisfaction and loyalty using a structural approach. International Journal of Hospitality Management, 29(2), 335-342. https://doi.org/10.1016/j.jhm.2009.10.002

Zeng, B., \& Gerritsen, R. (2014). What do we know about social media in tourism? A review. Tourism management perspectives, 10, 2736. https://doi.org/10.1016/j.tmp.2014.01.001

*** Ministry of Tourism and Creative Economy. (2015). Strategic Plan: Development of Tourism Industry and Destinations for 20152019. Jakarta: Ministry of Tourism and Creative Economy

*** Ministry of Tourism and Creative Economy. (2019). Press Release : Menpar Affirms Three Things Are Needed to Improve the Quality of 2020 Calendar of Events. Accessed by https://old.kemenparekraf.go.id/post/siaran-pers-menpar-unjukkan-perlu-tiga-halto-ingkatkan-kualitas-calender-of-event-2020 on March 12, 2021.

*** Ministry of Tourism and Creative Economy. (2019). Strategic Plan 2020-2024. Jakarta: Ministry of Tourism and Creative Economy. 